\title{
Pilihan Kata Sebagai Manifestasi Konsep Kesetaraan Gender Dalam Wacana Kampanye Un Women
}

\author{
Zewitra \\ Jurusan Bahasa Inggris, Politeknik Negeri Bandung, Indonesia \\ Email: zewitra@polban.ac.id
}

\begin{abstract}
RINGKASAN
Penelitian ini bertujuan untuk (1) menjelaskan nilai yang terkandung dalam pilihan kata yang digunakan dalam wacana kampanye kesetaraan gender UN Women dan (2) menjelaskan representasi konsep kesetaraan gender yang dimanifestasikan melalui pilihan kata yang digunakan dalam wacana kampanye tersebut. Objek penelitian adalah wacana-wacana kampanye kesetaraan gender yang diperoleh dari situs resmi UN Women (www.unwomen.org). Ditemukan lima belas wacana yang memiliki muatan kesetaraan gender dan pemberdayaan perempuan. Wacana-wacana ini dianalisis dengan menggunakan pendekatan Analisis Wacana Kritis berdasarkan teori Fairclough sebagai dasar untuk menemukan nilai yang terkandung dalam pilihan kata yang digunakan. Selanjutnya, metode interpretasi diaplikasikan untuk melihat representasi konsep kesetaraan gender yang termanifestasi melalui pilihan-pilihan kata tersebut. Penelitian ini menghasilkan dua simpulan. Pertama, pilihan kata yang digunakan dalam wacana kampanye kesetaraan gender UN Women mengandung tiga nilai, yaitu nilai eksperiental, nilai ekspresif, dan nilai relasional. Kedua, berdasarkan interpretasi terhadap pilihan kata, diperoleh tiga representasi konsep kesetaraan gender. Representasi 1 yaitu kesetaraan gender dipandang sebagai sebuah kondisi ketika perempuan ditempatkan pada posisi yang setara dan diberi kesempatan yang sama dengan laki-laki. Representasi 2 yaitu kesetaraan gender dinilai dapat membawa perubahan bagi masa depan yang lebih baik. Representasi 3 yaitu kesetaraan gender merupakan tanggung jawab semua pihak.
\end{abstract}

Kata Kunci: kesetaraan gender, wacana kampanye, representasi, analisis wacana kritis

\begin{abstract}
This current research is aimed to (1) explain the values of words choice used in the discourses of UN Women gender equality campaign and (2) explain the representations of gender equality concept manifested through the choice of words used in the discourses. The objects of this research are the discourses of gender equality campaign found in UN Women official website (www.unwomen.org). Fifteen discourses about gender equality and women empowerment were analized using Critical Dicourse Analysis approach in order to meet the purposes. Fairclough's theory was used in order to find the values contained in the choice of words. Moreover, the interpretation method was applied to acquire the representations of gender equality concept manifested through the choices of words. The research results in two important points. First, the choice of words used in discourses of UN Women gender equality campaign contains three values, which are experiential, expressive, and relational value. Second, there are three representations of gender equality concept found as a result of interpretation toward the choice of words. First, gender equality is seen as a condition when women and girls are placed in an equal position and given the same rights and opportunities as men. Second, gender equality is seen as a condition which is expected to bring changes for a better future. Third, gender quality is everybody's responsibility.
\end{abstract}

Key words: gender equality, campaign discourse, representation, critical discourse analysis 


\section{PENDAHULUAN}

Kampanye dapat dimaknai sebagai sebuah kegiatan atau rangkaian kegiatan yang dilakukan seseorang atau suatu kelompok dengan tujuan untuk menciptakan efek atau dampak tertentu. Newsom, Scott, dan Turk (1993: 474) berpendapat bahwa kampanye merupakan rangkaian usaha yang terkoordinasi dengan baik yang disusun untuk meraih suatu tujuan khusus. Tujuan khusus ini saling berhubungan dan pada akhirnya menggerakkan sebuah kelompok atau organisasi menuju objektif jangka panjang yang diungkapkan dalam visi dan misinya.

Sebagai sebuah badan sosial, UN Women (United Nations Entity for Gender Equality and the Empowerment of Women) pun menggunakan kampanye sebagai sarana untuk menyampaikan visi misi dan menyebarkan ideologinya kepada masyarakat. UN Women sendiri merupakan sebuah badan di bawah naungan PBB yang bergerak dalam bidang kesetaraan gender dan pemberdayaan perempuan. Misi jangka panjang UN Women adalah untuk menciptakan sebuah dunia yang adil bagi kaum perempuan dengan cara mengedukasi masyarakat mengenai konsep kesetaraan gender. Untuk itu, UN Women mengampanyekan konsep kesetaraan gender ini melalui wacana-wacana yang ditampilkan dalam situs resmi mereka, www.unwomen.org.

Sebuah kampanye, termasuk kampanye kesetaraan gender UN Women, tentunya tidak akan mencapai tujuan yang diinginkan tanpa adanya bahasa. Bahasa berperan penting dalam membawa pesan dan menyampaikan informasi. Munandar (2012: 96) bahkan menegaskan bahwa bahasa memberikan kontribusi yang sangat signifikan dalam menentukan kesuksesan sebuah kampanye.

Namun begitu, selain sebagai pembawa pesan, bahasa juga seringkali digunakan, dimanipulasi, dan dikemas untuk merekonstruksi suatu realitas sesuai dengan keinginan penutur (Fairclough, 1989: 2). Bahasa kerap dijadikan alat ampuh untuk menyebarkan dan mempertarungkan ideologi produsen. Bahasa yang telah direkonstruksi inilah yang kemudian terwujud dalam bentuk wacana.

Penggunaan bahasa dalam wacana menjadi fokus dalam penelitian ini. Bahasa yang digunakan dalam wacana kampanye kesetaraan gender UN Women pun telah dimanipulasi sedemikian rupa sehingga memuat nilai, paham, dan ideologi yang diyakini dan ingin disebarkan oleh UN Women. Penelitian ini bertujuan untuk (1) menjelaskan nilai yang 
terkandung dalam wacana kampanye kesetaraan gender UN Women berdasarkan pilihan kata yang digunakan dan (2) menjelaskan representasi konsep kesetaraan gender yang dimanifestasikan melalui pilihan kata yang digunakan dalam wacana kampanye UN Women.

\section{LANDASAN TEORI}

Landasan teori dari penelitian ini disusun berdasarkan kerangka pikir sebagai berikut. Kampanye merupakan kegiatan memproduksi wacana. Dalam praktiknya, kegiatan memproduksi wacana ini dipengaruhi oleh ideologi yang diyakini produsen yang kemudian terwujud dalam cara pandang produsen ketika memandang dan merepresentasikan realitas. Bentuk representasi ini dapat dibongkar dan diketahui dengan menggunakan pendekatan analisis wacana kritis. Mengikuti kerangka pikir ini, landasan teori disusun sebagai berikut (1) kampanye dan wacana kampanye, (2) ideologi dan representasi, dan (3) analisis wacana kritis.

\section{Kampanye dan Wacana Kampanye}

Kampanye kesetaraan gender yang diserukan oleh UN Women dapat digolongkan sebagai kampanye komunikasi publik. Rice dan Atkin (2001: 231-232) mendefinisikan kampanye komunikasi publik sebagai sebuah usaha terencana yang digunakan untuk menginformasikan, membujuk, atau memotivasi perubahan perilaku masyarakat. Kampanye jenis ini pada umumnya ditujukan untuk manfaat-manfaat sosial (noncommercial) pada kurun waktu yang ditentukan, melalui aktivitas komunikasi yang terencana dengan melibatkan media massa dan seringkali dilengkapi dengan dukungan interpersonal.

Aktivitas kampanye memanfaatkan bahasa untuk menyampaikan maksudnya. Bahasa direkonstruksi sedemikian rupa untuk membawa ideologi produsen. Bahasa yang telah direkonstruksi ini terwujud dalam bentuk wacana.

Dalam pandangan linguistik kritis, wacana dipandang sebagai sesuatu yang lebih besar dari kalimat semata. Wacana adalah sarana dan media yang digunakan seseorang atau kelompok untuk menyebarkan dan menanamkan ideologinya (Foucault dalam Eriyanto, 2001: 66-73). Fairclough (1997: 131) kemudian juga melihat wacana sebagai 
sebuah praktik sosial yang dikonstruksi melalui kekuatan kekuasaan dan ideologi produsen.

Sebagaimana halnya dengan jenis wacana lain, wacana kampanye tentunya juga dikonstruksi untuk menyampaikan maksud-maksud tertentu. Proses produksi wacana kampanye juga dipengaruhi oleh ideologi dan kepercayaan produsen terhadap suatu realitas. Ideologi dan kepercayaan ini kemudian terwujud dalam cara produsen merepresentasikan sesuatu.

\section{Ideologi dan Representasi}

Linguistik kritis memandang ideologi sebagai sesuatu yang memengaruhi produksi sebuah wacana. Ideologi sendiri merupakan sistem ide, seperangkat pola-pola kepercayaan, seperangkat nilai, perspektif, atau pandangan terhadap dunia dan representasinya yang terus dipegang dan diperjuangkan oleh sebuah kelompok yang meyakininya (Santoso, 2012: 59).

Dalam praktik produksi wacana, ideologi yang diyakini oleh seseorang, suatu kelompok, atau singkatnya produsen wacana kemudian bermanifestasi menjadi perspektif, sudut pandang, atau bingkai yang dipahami sebagai pengetahuan akan sebuah konsep (Renkema, 2004: 236). Sudut pandang atau bingkai ini tidak hanya memfokuskan perhatian sasaran tutur kepada masalah tertentu, tetapi juga membatasi persepsi dan mengarahkan mereka kepada cara pikir dan keyakinan tertentu yang sejalan dengan ideologi produsen. Hal inilah yang kemudian terwujud dalam representasi produsen dalam menggambarkan sebuah realitas.

Representasi sendiri dapat diartikan sebagai aktivitas pembentukan makna melalui bahasa (Hall, 2003: 15-16). Dalam ranah linguistik kritis, Eriyanto (2011: 113) menyatakan bahwa representasi merujuk kepada bagaimana seseorang, suatu kelompok, sebuah gagasan, maupun pendapat ditampilkan dalam sebuah teks wacana dengan tujuan untuk membangun citra, mengunggulkan diri sendiri, dan pada saat yang sama, memarginalkan kelompok atau gagasan lain.

Sebagai sebuah hasil dari aktivitas berbahasa, jejak-jejak representasi yang terkandung dalam sebuah wacana tentu dapat ditelusuri dari penggunaan bahasanya. Untuk itu, diperlukan sebuah analisis wacana secara kritis yang digunakan untuk 
menganalisis praktik penggunaan bahasa sebagai upaya untuk mengetahui bagaimana produsen merepresentasikan sebuah konsep.

\section{Analisis Wacana Kritis}

Analisis Wacana Kritis (AWK) adalah sebuah pendekatan yang digunakan untuk melihat dan membongkar praktik-praktik ideologi dan latar belakang yang tersembunyi di balik sebuah wacana. Banyak ahli yang telah merumuskan beragam teori mengenai AWK, namun para ahli tersebut sama-sama melandaskan pandangan mereka kepada bahasa sebagai praktik sosial, tempat suatu kelompok memantapkan dan menyebarkan ideologinya (Fairclough, 1997: 131).

Van Dijk, Fairclough, dan Wodak (dalam Eriyanto, 2001: 8-15) memberikan lima karakteristik penting dari analisis wacana kritis. Pertama, wacana dipahami sebagai sebuah tindakan sehingga wacana merupakan sesuatu yang bertujuan dan diekspresikan secara sadar dan terkontrol. Kedua, AWK mempertimbangkan konteks dari wacana, seperti latar, situasi, peristiwa, dan kondisi walaupun dalam analisis wacana konteks partisipan dan latar sosial lebih memegang peranan penting dalam proses produksi sebuah wacana. Ketiga, aspek historis adalah aspek penting dalam sebuah wacana karena wacana yang berkembang akan sesuai dengan kejadian yang terjadi pada saat itu. Keempat, konsep kekuasaan adalah salah satu kunci hubungan antara wacana dan masyarakat. Kelima, ideologi juga merupakan konsep sentral dalam analisis wacana yang bersifat kritis karena ideologi dibangun oleh kelompok dominan dengan tujuan mereproduksi dan melegitimasi ideologi mereka.

\section{METODOLOGI PENELITIAN}

Objek penelitian ini adalah lima belas wacana kampanye kesetaraan gender dalam situs resmi UN Women (www.unwomen.org). Wacana-wacana yang ditemukan di situs ini tidak hanya berasal dari atau dituturkan oleh pihak UN Women sendiri. Sebagian besar wacana tersebut justru berasal dari pihak lain, seperti masyarakat umum yang mendukung, ikut berpartisipasi, dan merasakan dampak dari kesetaraan gender. Wacanawacana ini kemudian dianalisis untuk melihat nilai yang terkandung dalam pilihan kata sekaligus mengetahui representasi kesetaraan gender menurut nilai-nilai tersebut. 
Untuk mencapai tujuan pertama, penelitian ini berpijak pada teori Fowler tentang linguistic tools untuk melihat manifestasi sebuah konsep tertentu dalam aspek kebahasaan. Penelitian ini hanya mengambil fitur linguistik pilihan kata sebagai salah satu fitur yang membawa fungsi ideasional. Fungsi ideasional sendiri adalah fungsi bahasa untuk mengungkapkan ide (Halliday dan Matthiessen, 2004: 61).

Rumusan masalah kedua dijawab dengan metode interpretasi. Jawaban dari rumusan masalah pertama diinterpretasikan, diterjemahkan, dan diformulasikan sedemikian rupa sehingga menghasilkan konsep representasi kesetaraan gender yang terkandung dalam wacana kampanye kesetaraan gender UN Women. Representasi sendiri adalah sebuah aktivitas pembentukan makna melalui bahasa, bagaimana bahasa digunakan untuk menyatakan sesuatu yang bermakna, atau bagaimana mendeskripsikan dunia secara bermakna kepada orang lain (Hall, 2003).

\section{HASIL DAN PEMBAHASAN}

Nilai pilihan kata yang terkandung dalam wacana kampanye kesetaraan gender di situs UN Women

Pilihan kata merupakan pemetaan sebuah objek, konsep, proses, maupun hubungan kebudayaan yang dibutuhkan dalam proses komunikasi (Fowler, 1996: 80). Terdapat dua terminologi dalam semantik filosofis yang digunakan untuk membedakan makna sebuah kata. Terminologi pertama adalah referensi (reference). Referensi adalah makna kata jika dilihat dari objek yang diacunya. Terminologi kedua disebut dengan sense, yaitu makna kata yang dilihat dari hubungan antara satu kata dengan kata lain. Makna kata tidak ada kaitannya dengan objek fisik yang diacu (Fowler, 1996: 81-82).

Terminologi kedua inilah yang digunakan dalam memproduksi sebuah wacana. Kosakata bukan hanya digunakan secara acak atau random, namun pemilihan kosakata berkaitan dengan bagaimana produsen melihat dan memaknai suatu realitas dan mengonstruksinya kembali menjadi sebuah wacana yang akan disampaikan kepada masyarakat. Pemilihan kosakata ini memungkinkan produsen untuk mengontrol dan mengatur pengalaman pada realitas sosial (Eriyanto, 2001: 134). Fairclough (1989: 114) juga menyebutkan bahwa kata sering digunakan dengan tujuan untuk pertarungan ideologi (ideologically contested). 
Dalam proses pemilihan kata untuk memproduksi suatu wacana, terdapat tiga nilai yang harus diperhatikan (Fairclough, 1989: 110-120). Nilai pertama adalah nilai pengalaman (experiential value). Sebuah kata dikatakan memiliki nilai eksperiental apabila kata tersebut merepresentasikan pengalaman dan cara pandang produsen dalam melihat realitas. Nilai kedua adalah nilai ekpresif (expressive value). Kata yang memiliki nilai ekspresif memperlihatkan sikap dan penilaian produsen terhadap realitas. Nilai terakhir yang dimiliki sebuah kata adalah nilai relasional (relational value). Kata yang memiliki nilai relasional menujukkan hubungan sosial yang terjadi antara partisipan dalam sebuah wacana.

Berdasarkan pelacakan terhadap lima belas wacana kampanye kesetaraan gender di situs UN Women, ditemukan 75 kalimat yang mengandung muatan kesetaraan gender. Selanjutnya, pilihan kata pada setiap kalimat diklasifikasikan sesuai dengan nilai masingmasing. Dalam proses ini, diperoleh 86 pilihan kata yang mengandung nilai eksperiental, 38 kata yang mengandung nilai ekspresif, dan 13 kata yang mengandung nilai relasional.

\section{Pilihan kata pembawa nilai eksperiental}

Kata dengan nilai eksperiental merepresentasikan pengalaman dan cara pandang produsen wacana dalam melihat realitas (Fairclough, 1989: 112). Pengalaman dan cara pandang yang berbeda akan akan menghasilkan wacana dengan pilihan kata yang berbeda pula. Masing-masing kata yang digunakan mencerminkan ideologi tertentu yang diyakini oleh produsen.

Dalam analisis terhadap data yang ada, ditemukan 86 kata atau frasa yang mengandung nilai eksperiental. Beberapa kata digunakan berulang kali untuk menegaskan makna, seperti contribution, opportunity, dan change.

1. We need men who will stand up for the rights of women and girls.

2. On the World Water Day, I spoke to the villagers about the need for women to be included in water management.

3. I called on men to invite more women to important meetings.

Kutipan (1) memperlihatkan bahwa produsen memandang kesetaraan gender sebagai sebuah hak yang harus diperoleh oleh kaum perempuan sehingga semua lapisan masyarakat, terutama laki-laki, diharapkan mau berjuang demi tercapainya cita-cita ini. 
Salah satu hak tersebut dikemukakan dalam kutipan (2), kesetaraan gender terjadi apabila kaum perempuan diikutsertakan dalam kegiatan sosial kemasyarakatan, dalam hal ini adalah mengenai pengelolaan air. Begitu juga seperti yang diutarakan dalam kutipan (3) yang mengisyaratkan bahwa kesetaraan gender dapat tercapai apabila perempuan dilibatkan dalam pertemuan-pertemuan penting lain di masyarakat.

\section{Pilihan kata pembawa nilai ekspresif}

Kata-kata dengan nilai ekspresif menunjukkan sikap dan penilaian produsen terhadap realitas. Podusen mengekspresikan penilaiannya dengan cara membuat skema klasifikasi yang memuat evaluasi dan memperjuangkan ideologi-ideologi tertentu (Fairclough, 1989: 119).

Menurut Santoso (2012: 141), nilai ekspresif suatu kosakata dapat dilihat dari evaluasi positif atau negatif yang dibawa oleh kosakata tersebut. Dalam wacana kampanye kesetaraan gender di situs $U N$ Women, tentunya pilihan kata bermuatan positiflah yang banyak digunakan untuk merepresentasikan konsep kesetaraan gender.

4. ... but I want a better future for my children, I want to live in peace.

5. We can access bank services and we know of opportunities to improve our lives.

Kutipan-kutipan di atas memuat beberapa contoh pilihan kata dengan nilai-nilai positif. Kesetaraan gender dinilai akan membuat perempuan memiliki masa depan yang lebih baik (better future) dengan cara meningkatkan kehidupan mereka (improve our lives).

6. ... and their contributions are vital for both rural communities and urban societies.

7. Everyone plays an important role because sustainable peace doesn't just benefit one, it benefits all.

Kesetaraan gender tidak hanya membawa perubahan bagi nasib kaum perempuan. Lebih jauh, konsep ini juga membawa perubahan yang lebih baik bagi kehidupan sosial masyarakat dan dunia secara umum. Pada kutipan (6), digunakan kata vital yang memperlihatkan pentingnya kontribusi perempuan di dalam kehidupan bermasyarakat. Selanjutnya, dalam kutipan (7), secara jelas disebutkan bahwa kesetaraan gender akan bermanfaat bagi semua pihak. 


\section{Pilihan kata pembawa nilai relasional}

Kata yang mengandung nilai relasional menunjukkan hubungan antara partisipan yang terlibat dalam wacana (Fairclough, 1989: 112). Pilihan kata ini membantu menciptakan hubungan sosial antara penutur dan sasaran tutur. Hubungan antara partisipan juga dapat terlihat dari penggunaan kata-kata eufimistik, kata-kata formal, kata-kata informal, sapaan, nama, dan rujukan pribadi (Santoso, 2012: 141).

Berdasarkan hasil analisis terhadap wacana kampanye kesetaraan gender ditemukan tiga belas pilihan kata yang memuat nilai relasional dan sebagian besar di antaranya berjenis kata sapaan.

8. All of us need to change this, and it might take a long time and a lot of struggle and energy.

9. We need men who will stand up for the rights of women and girls.

10. We are pressing the Government to recognize that women are farmers and to give them access to markets, economic goods, and all the other things that they need as farmers.

Sasaran tutur pada kutipan (8) adalah all of us, sasaran tutur pada kutipan (9) adalah men, dan sasaran tutur pada kutipan (10) adalah the Government. Hal ini menyiratkan bahwa UN Women menghimbau semua pihak, baik laki-laki maupun perempuan, baik rakyat biasa maupun pemerintah, untuk dapat bekerja sama dalam mencapai kesetaraan gender. Dengan kata lain, UN Women menempatkan dirinya setara dengan seluruh sasaran tuturnya.

\section{Representasi konsep kesetaraan gender}

Representasi merupakan sebuah aktivitas pembentukan makna melalui bahasa, bagaimana bahasa digunakan untuk menyatakan sesuatu yang bermakna, atau bagaimana mendeskripsikan dunia secara bermakna kepada orang lain (Hall, 2003: 15). Eriyanto (2011: 113) berpendapat bahwa representasi merujuk pada bagaimana seseorang, suatu kelompok, sebuah gagasan maupun pendapat ditampilkan dalam sebuah teks wacana dengan tujuan untuk membangun citra, mengunggulkan diri sendiri, dan pada saat bersamaan memarginalkan gagasan atau kelompok lain. 
Berdasarkan penggunaan kata dan nilai yang dimiliki oleh masing-masing kata, diperoleh tiga representasi yang merupakan manifestasi konsep kesetaraan gender menurut UN Women.

\section{Representasi 1: Kesetaraan gender dipandang sebagai sebuah kondisi ketika perempuan ditempatkan pada posisi yang setara dan diberi kesempatan yang sama dengan laki-laki.}

Dari hasil penelitian ditemukan 86 (delapan puluh enam) pilihan kata yang mengandung nilai eksperiental yang digunakan untuk merekonstruksi wacana kampanye kesetaraan gender di situs UN Women. Beberapa pilihan kata tersebut antara lain:

woman leader, public service, transformation, advocating girls' and women's education, encouraging, change, unite, winning the top leadership positions, opportunity, can earn income, stand up, the rights for women and girls, to be included, women's empowerment, end gender-based violence, priority, dsb

Dilihat dari pilihan-pilihan kata yang ada dapat ditarik kesimpulan bahwa UN Women memandang kesetaraan gender sebagai sebuah hak bagi perempuan (rights) di mana perempuan diberi kesempatan yang sama dengan laki-laki. Hal ini terlihat dari pilihan-pilihan kata yang digunakan. Kesempatan untuk menjadi pemimpin terlihat dalam pilihan kata women leader, winning the top of leader positions. Kesempatan mendapatkan layanan dan pendidikan yang layak seperti terlihat dari penggunaan kata public service and education. Kesempatan memperoleh penghasilan sendiri yang terlihat dari pemakaian kata can earn income, dan sebagainya. Dengan kata lain, kesetaraan gender adalah sebuah kondisi di mana perempuan ditempatkan pada posisi yang setara dan diberi kesempatan yang sama dengan laki-laki (representasi 1).

\section{Representasi 2: Kesetaraan gender dinilai dapat membawa perubahan bagi masa depan yang lebih baik.}

Seperti telah dijelaskan sebelumnya, pilihan kata pembawa nilai ekspresif menunjukkan sikap dan penilaiaan produsen terhadap realitas. Podusen mengekspresikan penilaiannya dengan cara membuat skema klasifikasi yang memuat evaluasi dan memperjuangkan ideologi-ideologi tertentu (Fairclough, 1989: 119). Dari hasil pelacakan 
terhadap wacana kampanye UN Women, ditemukan 38 pilihan kata dengan muatan ekpresif, di antaranya:

vital, better future, improve livehoods and well-being, shape the lives, greater awareness and confidence, optimistic, empowered women, effective leader, victory, proud, change lives, means a lot, benefit all, possible to achieve, meaningful, move forward, remarkable chances, dst

Berdasarkan pilihan-pilihan kata yang membawa nilai ekspresif ini, terlihat bahwa kesetaraan gender dinilai sebagai sesuatu yang positif. Kesetaraan gender dinilai membawa kebaikan bagi para perempuan itu sendiri. Hal ini dibuktikan dengan penggunaan kata-kata seperti better future, impove livehoods and well-being, shape the lives, dan sebagainya. Selain itu, kesetaraan gender juga dinilai sebagai sesuatu yang membawa dampak besar bagi kehidupan masyarakat pada umumnya. Hal ini terlihat dari penggunaan kata-kata seperti vital, effective leader, victory, benefit all, dan seterusnya. Oleh karena itu, dapat disimpulkan bahwa kesetaraan gender dinilai sebagai sesuatu yang positif yang dapat membawa perubahan bagi masa depan yang lebih baik (representasi 2).

\section{Representasi 3: Kesetaraan gender merupakan tanggung jawab semua pihak.}

Representasi terakhir yang dilihat dari wacana kampanye kesetaraan gender di situs UN Women berkaitan dengan nilai relasional yang terdapat kata-kata tertentu. Pilihan kata dengan nilai relasional memperlihatkan hubungan antara partisipan yang terlibat dalam wacana. (Fairclough, 1989: 112). Pilihan kata ini membantu menciptakan hubungan sosial antara penutur dan sasaran tutur.

Berdasarkan penelusuran terhadap wacana kampanye UN Women, ditemukan tiga belas pilihan kata yang mengandung nilai relasional. Semua pilihan kata tersebut memperlihatkan hubungan antara produsen wacana (dalam hal ini UN Women) dengan pihak yang disasar dalam kampanye ini. Beberapa pilihan kata tersebut antara lain:

together, one another, we, with rural women and their organizations everywhere, all of us, you, men, the government, communities and people. 
Dalam pilihan-pilihan kata ini terlihat bahwa UN Women memanggil seluruh kalangan untuk berpartisipasi dalam kampanye kesetaraan gender. Dengan menggunakan kata ganti we dan all of us, UN Women menginsyaratkan bahwa masalah kesetaraan gender adalah tanggung jawab semua pihak, laki-laki dan perempuan serta pemerintah dan masyarakat (representasi 3).

\section{SIMPULAN}

Penelitian terhadap wacana kampanye kesetaraan gender di situs UN Women menemukan bahwa pilihan-pilihan kata yang digunakan dalam wacana ini mengandung tiga nilai penting, yaitu (i) nilai eksperiental, (ii) nilai ekspresif, dan (iii) nilai relasional. Berdasarkan pelacakan terhadap nilai eksperiental, diperoleh simpulan bahwa UN Women memandang kesetaraan gender sebagai sebuah kesamaan, keadilan, keamanan, kemajuan, dan sebagainya. Selanjutnya, dilihat dari nilai ekspresif, pilihan kata yang digunakan untuk menggambarkan konsep kesetaraan gender cenderung bermuatan positif. Wacana ini menggunakan menggunakan kata sapaan informal untuk membentuk hubungan dengan sasaran tutur.

Dari hasil penelusuran terhadap pilihan kata ini, diperoleh tiga representasi kesetaraan gender menurut UN Women. Representasi pertama dilihat dari pilihan kata yang membawa nilai eksperiental. Berdasarkan pilihan-pilihan kata ini, kesetaraan gender dipandang sebagai sebuah kondisi ketika perempuan ditempatkan pada posisi yang setara dan diberi kesempatan yang sama dengan laki-laki. Selanjutnya, representasi kedua dilihat dari pilihan kata yang memuat nilai ekspresif. Berdasarkan pilihan-pilihan kata ini, kesetaraan gender dinilai sebagai sesuatu yang positif yang dapat membawa perubahan bagi masa depan yang lebih baik. Terkahir, representasi ketiga diinterpretasikan dari pilihan-pilihan kata pembawa nilai relasional. Berdasarkan analisis terhadap pilihanpilihan kata ini, disimpulkan bahwa kesetaraan gender adalah sesuatu yang harus diusahakan bersama dan merupakan tanggung jawab semua pihak, laki-laki dan perempuan serta pemerintah dan masyarakat. 


\section{UCAPAN TERIMA KASIH}

Penelitian ini didanai oleh DIPA POLBAN dengan nomor kontrak 856.17/PL1.R7/LT/2018.

\section{DAFTAR PUSTAKA}

Eriyanto. (2011). Analisis wacana, pengantar analisis teks media. Yogyakarta: LkiS Group. (2013). Analisis naratif: Dasar-dasar dan penerapannya dalam analisis teks berita media. Jakarta: Kencana.

Fairclough, N. (1989). Language and power. New York: Longman Inc. . 1997. Critical discourse analysis: The critical study of language. United States of America: Longman Inc. . (2006). Discourse and social change. Cambridge: Polity Press.

Fowler, R. (1996). Language in the news. Discourse and ideology in the press. New York: Routledge.

Hall, S. (2003). Representation. London: Sage Publication Ltd.

Halliday, M.A.K. dan Matthiessen, C. M.I.M. (2004). An introduction to functional grammar. New York: Oxford University Press.

Leeuwen, T. (2008). Discourse and practice. Oxford: Oxford Unversity Press.

Munandar, A. (2012) “Simple, yet powerful English of MoveOn's campaigns” dalam Humaniora Volume XXIV, No. 1/2012: 95-103.

Newsom, D., Scott, A., dan Turk, J.V. (1993). This is PR: The realities of public relations. Belmont: Wardsworth.

Santoso, A. (2012). Studi bahasa kritis menguak bahasa membongkar kuasa. Bandung: CV. Mandar Maju.

Sirulhaq, A. (2008). "Ideologi gender bahasa berita Samarinda Pos dalam merepresentasikan perempuan (Studi Analisis Wacana Kritis)". Tesis Sekolah Pascasarjana FIB Universitas Gadjah Mada. tidak dipublikasikan.

Wodak, R. dan Meyer, M. (2001). Methods of Critical Discourse Analysis. London: Sage Publication. 
Wodak, R. dan Clinton, P. (2005). A new agenda in (Critical) Discourse Analysis. Amsterdam / Philadephia: John Benjamins Publishing Company. 